\title{
Learning and working: double statuses in youth transitions within the European Union
}

Citation for published version (APA):

Wolbers, M. H. J. (2001). Learning and working: double statuses in youth transitions within the European Union. Researchcentrum voor Onderwijs en Arbeidsmarkt, Faculteit der Economische Wetenschappen. ROA Research Memoranda No. 6E https://doi.org/10.26481/umaror.200106E

Document status and date:

Published: 01/01/2001

DOI:

10.26481/umaror.200106E

Document Version:

Publisher's PDF, also known as Version of record

\section{Please check the document version of this publication:}

- A submitted manuscript is the version of the article upon submission and before peer-review. There can be important differences between the submitted version and the official published version of record.

People interested in the research are advised to contact the author for the final version of the publication, or visit the DOI to the publisher's website.

- The final author version and the galley proof are versions of the publication after peer review.

- The final published version features the final layout of the paper including the volume, issue and page numbers.

Link to publication

\footnotetext{
General rights rights.

- You may freely distribute the URL identifying the publication in the public portal. please follow below link for the End User Agreement:

www.umlib.nl/taverne-license

Take down policy

If you believe that this document breaches copyright please contact us at:

repository@maastrichtuniversity.nl

providing details and we will investigate your claim.
}

Copyright and moral rights for the publications made accessible in the public portal are retained by the authors and/or other copyright owners and it is a condition of accessing publications that users recognise and abide by the legal requirements associated with these

- Users may download and print one copy of any publication from the public portal for the purpose of private study or research.

- You may not further distribute the material or use it for any profit-making activity or commercial gain

If the publication is distributed under the terms of Article $25 \mathrm{fa}$ of the Dutch Copyright Act, indicated by the "Taverne" license above, 


\section{Learning and Working:}

Double Statuses in Youth Transitions within the European Union

ROA-RM-2001/6E

Maarten Wolbers

Research Centre for Education and the Labour Market

Faculty of Economics and Business Administration

Maastricht University

Maastricht, November 2001 
ISBN 90-5321-321-X

Sec01.003.doc/MW 


\section{Contents}

Page

1 Introduction 1

2 Double status positions and the expected effects of the institutional context

3 Data and variables

4 Double status positions among young people

5 Labour market outcomes of young people in a double status position

6 Conclusion

Notes 



\section{Introduction*}

The transition from school to work is a phase of life in which young people are introduced to the world of labour. This transition process is often far from smooth and it can be characterized as a turbulent and precarious period (OECD 1998; Kerckhoff 2000). First of all, the transition from school to work refers to a process in which young people face periods of unemployment quite often and end up frequently in jobs that do not match their education very well. Secondly, the transition from school to work can not be considered as a single event from full-time initial education to stable full-time employment (see Scherer 2001). Instead, the labour market entry of young people should be described as a complex and prolonged allocation process, of which it is hard to define at what point it really starts and when it exactly ends (OECD 1996, 2000). Often, there is some kind of gradual labour market entry, where young people combine their studies with work. This is partly the result of pupils participating in apprenticeship programmes, but also because of students having (part-time) jobs. Moreover, the recent attention for lifelong learning as a continuous investment in human capital during the working career has blurred the transition process.

In this paper we aim to provide insight in the extent, structure, and recent development of combinations of learning and working among young people within the European Union. Three types of 'double statuses' are distinguished: young people who combine learning and working in the dual system, full-time students who have jobs, and employed individuals who invest in training to advance their working career. The analysis of these double status positions offers the opportunity to look in detail at how the pathways from school to work are organized in different institutional contexts of Europe. This should lead to a better understanding of the trajectories of young people from initial education to a stable position in the labour force. In addition, we look at some labour market outcomes of young people that are in a double status position. The aim is to shed some more light on the issue whether or not a double status position serves as a stepping stone towards stable employment. For that reason, we investigate to what extent double status positions go together with specific job characteristics that differ from the employment situation of those who are regular employed and whether there are institutional differences in this respect.

The paper is structured as follows. In the second section we derive some hypotheses on differences in the occurrence of double status positions among young people in the European Union. The third describes the data and variables to be used in measuring double statuses. The fourth presents the occurrence of double status positions among young people in different institutional contexts of Europe. The fifth looks at three characteristics of the jobs held by young people who combine learning and working: the permanency of the job, the distinction between full-time and part-time work, and the occupational status attained. The sixth discusses the main conclusions of the paper. 


\section{Double status positions and the expected effects of the institutional context}

A traditional way of combining learning and working is the dual system. This apprenticeship system of vocational education refers to a situation in which pupils receive on-the-job training in the company in which they work almost full-time, while at the same time attending some day-release programmes at school. In general, the dual system is open for pupils from $15 / 16$ years and over, with or even without a diploma at the lower level of secondary education. The courses last up to three years, depending upon the initial educational qualifications. A crucial feature of the dual system is that all actors - employers, unions, and the government - are involved and together set up the training programmes, the curricula, the standards of instruction, and the examinations (Crouch, Finegold and Sako 1999). Pupils in the apprenticeship system are usually employees at the same time. They are not only covered by the provisions of the apprenticeship agreement, but also by the legal rights and duties of a regular employment contract, although their contract is mostly limited for the duration of the training. Given this nature of apprenticeships as being essentially regular work contracts, pupils in the dual system are often paid, although below the level of minimum wages.

The popularity of the dual system has increased considerably during the post-war period. An important reason for this is that in those days the industry required large numbers of young individuals, who could be trained in a relatively short period (OECD 1994). The structure of the apprenticeship system was created in such a way that it could serve the different branches of industry. In Germany, for example, this has resulted in a qualitatively extensive system of training regulations in hundreds of occupations. Besides occupations in industry, it concerned in particular jobs in craft and - to a lesser extent - service sectors. In more recent years, however, the number of apprenticeships in countries that had reasonably large dual systems has stabilised or even declined. An important reason for this is that the dual system is not flexible enough to adjust to current changes in the occupational structure, most notably the employment shift from manufacturing to the service sector (Blossfeld 1992; see also Mayer 1995). In countries such as France, on the other hand, the number of pupils in the apprenticeship system seems to grow, mainly as a consequence of a growing involvement of firms and employers in the provision of apprenticeships (Goux and Maurin 1998; Crouch, Finegold and Sako 1999).

Apart from combining learning and working in the apprenticeship system, there is the increased labour market participation of students (Hutson and Cheung 1992; Hakim 1998; Van der Meer and Wielers 2001). Today, many students have regular jobs, not just in the summer holidays, but also during the academic year. Well known are the examples of young people delivering newspapers or helping in shops on Saturdays or in restaurants in the evening hours. In general, student jobs are taken on a temporary or short term basis, even if the job itself may contractually be a permanent one. Furthermore, the jobs that students hold are typically part-time jobs, since they have to combine these jobs with their full-time educational activities. The level of occupation may vary, although the majority of student employment is in semi-skilled or unskilled jobs requiring little specific training. 
There are two main economic arguments that may explain the rising trend in student jobs. The first reason is the relative decline in funding for higher education. Since most modern societies have moved to a mass higher education system, it has become almost impossible for national governments to give extensive grants to students to pay their living expenses and therefore some of them decided in the 1990s to reduce student grants. As a consequence, this measure forced students to take jobs in order to pay for their studies and to cover their living costs. From the labour demand side, there is also an argument for expecting an increasing number of working students: the numerical flexibilisation of the labour force. There are two processes that indicate that the European labour market has become more flexible recently (Delsen 1995). First of all, much of the recent employment growth in European countries can be ascribed to the creation of part-time jobs. Secondly, the labour markets in Europe have become more flexible by the increased share of people who work in fixed-term contracts, or through temporary employment agencies. Both processes have facilitated student employment, because employers find students especially interesting in this respect (Van der Meer and Wielers 2001). Students are flexible in the sense that they are often without any daily obligations (such as family life) beyond college hours and they can often work at irregular (evening) hours. This makes them very attractive for employers who offer short-term contracts or part-time jobs.

A third form of combining learning and working is the attendance of continuing training while working. In contrast to the other two double status positions, the educational component here is continuous training instead of initial education. In general, this kind of additional training refers to enterprise-related training and it often has the function of bridging any gaps that may exist between skills which are demanded on the work floor and those that employees possess (Barron, Black and Loewenstein 1989; Van Smoorenburg and Van der Velden 2000). ${ }^{1}$ According to Thurow (1975), on-the-job training can be considered as a way to obtain the knowledge and skills necessary to adequately perform a job. The initial educational background is often only used as a 'screening device' to judge the school leavers' trainability (Arrow 1973). Enhancing productive skills, however, takes place by means of specific enterprise-related training. Studying workers are in the early stages of their career with their current employer and in this period they need to do some extra training to acquire firm-relevant skills. Only after finishing this training and applying these skills successfully in the firm, employers will change temporary contracts into permanent ones. It is therefore expected that studying workers less often have permanent jobs than regular workers. Moreover, studying workers are more likely to be in part-time jobs, since their investments in additional training have to be combined with work.

It can be assumed that the occurrence of double status positions in the transition process differs across various institutional contexts. In general, segmentation theories contrast two types of labour market structures: internal labour markets (ILM) versus occupational labour markets (OLM) (Maurice, Sellier and Silvestre 1986; Marsden 1990; see also Gangl 1999). The crucial difference between them lies in the access to skilled labour market positions and it is evident that the organization of the education and training system plays a key role in this distinction. 
In countries dominated by internal labour markets, newcomers start in entrance jobs ('ports of entry'). The career patterns or profiles within internal labour markets depend to a large extent on the acquired on-the-job training (Doeringer and Piore 1971). By means of additional training, individuals obtain the skills that are necessary to make internal upward moves (often within the same firm). In other words, the intensity of training during working life is expected to be high in internal labour markets. In countries dominated by occupational labour markets, on the other hand, a very different allocation process is applied. In the labour markets of these countries, there is a close link between the specific skills learnt in vocational education and the skills required on the labour market (Hannan, Raffe and Smyth 1997; Müller and Shavit 1998). Access to skilled jobs is reserved for those workers who have mastered the specific skills needed for these jobs. This means that the existence of occupational labour markets is closely related to the existence of a training system that produces workers with occupation-specific skills. Furthermore, the acquired skills have high levels of consistency across firms or even industries, are transferable across employers, and are recognised as such (Eyraud, Marsden and Silvestre 1990; Shavit and Müller 2000). On the basis of this distinction in the production of skills, we derive the hypothesis that studying workers are more likely to be found in ILM countries than in OLM ones. With regard to dual system students we expect the opposite. In OLM countries, a model of workplace training combined with vocational schooling has been adopted, which leads to many young people going through this dual system.

With respect to working students, the ILM versus OLM contrast applies too, although less distinctly. As indicated above, financial need is expected to be a driving force behind the increased labour market participation of students. Especially in countries with mass higher education, government subsidies for students' living expenses have fallen strongly and, therefore, the financial pressure for students to work is high. Since the recent expansion of higher education has been stronger in ILM countries than in OLM ones (see Müller and Wolbers 1999), we expect that in the former countries students are more likely to hold a job than in the latter. Moreover, in ILM arrangements unskilled or semi-skilled (student) jobs are rather easy accessible without the proper qualifications because of the entry-port employment structure in internal labour markets. In OLM countries, however, where access to jobs is much more closed for individuals without the required skills, it is likely that students have more difficulties finding jobs (which bear hardly any relationship to their studies).

\section{Data and variables}

The data used in the analysis that follows come from the European Community Labour Force Survey (ECLFS) data set as held in the period 1992-97. ${ }^{2}$ We analyse only those respondents who are aged between 15 and 39 years in order to capture young people who are in the transition process.

To define young people in a double status position, we start to combine information on education and training activities during the last four weeks (in education versus not in education) by the employment status (employed versus not employed). ${ }^{3}$ This provides us 
with four distinct categories of education and employment activities: (1) employed; in education, (2) employed; not in education, (3) not employed; in education, and (4) not employed; not in education. ${ }^{4}$ The first category includes all combinations of learning and working. Within this category, the three double status positions (dual system student, working student and studying worker) are differentiated. In principal, the distinction between working students and studying workers is established on the basis of information on the purpose of the received education or training. If the purpose of the education is initial training, individuals are defined as working students. If the purpose is continuous training, they are studying workers. Employed individuals who attend a school that provides general education are always classified as working students. Furthermore, those who receive specific education in a working environment or study for some other qualification, are treated as studying workers. Dual system students are defined as employed young people who receive specific vocational training within a system that provides both work experience and complementary instruction elsewhere (any form of 'dual system' including apprenticeship). Individuals who receive training in any form of a dual system, but for whom this is not initial but continuous training, are labelled as studying workers. ${ }^{5}$

To illustrate that these three combinations of learning and working are distinct in the data, we plot the age distribution of each double status position in Figure $1 .{ }^{6}$ In this figure, it can be seen that the modal age of dual system students in the European Union is 18 years. About 22 per cent of all dual system students is aged 18. This percentage drops fast as age increases. At the age of 22, it stands below five per cent. The deviation around the modal age is relative small if we compare it to that of working students and studying workers. The modal age of working students is even lower than that of dual system students (16 years), but the proportion of working students at later ages drops only gradually (from 11 per cent for those who are 17 years old to still five per cent for those aged 25). The modus of studying workers is around 27 years of age, consisting of five per cent of all studying workers. Just like in the case of working students, there is no real peak.

Figure 1

Age distribution of double status positions

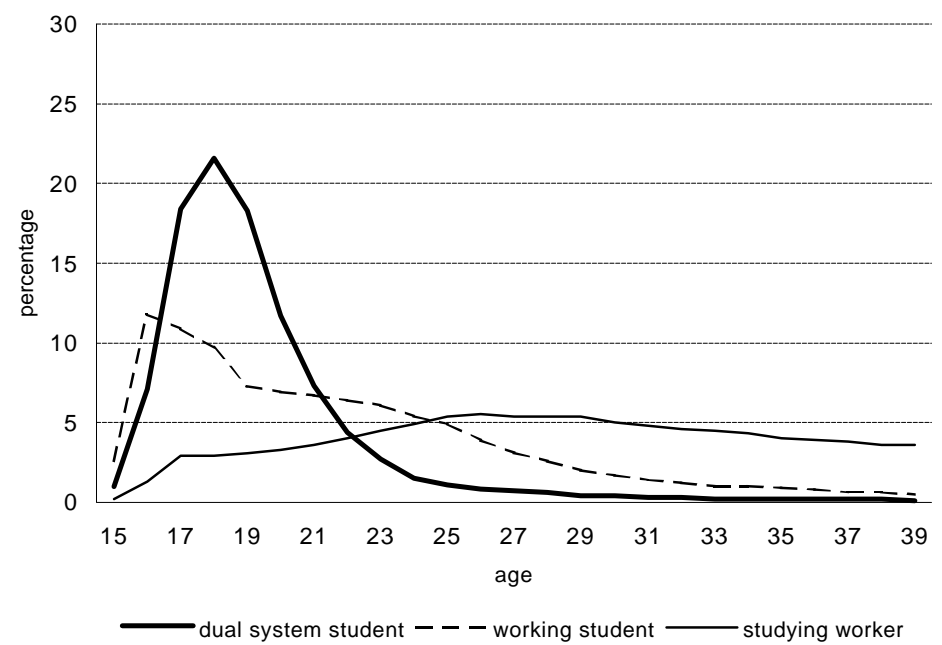

Source: pooled ECLFS-data 1992-97 
To determine the effects of the institutional context, we specify a grouping of countries that represents the main institutional systems affecting the labour market entry of young people within Europe (see Gangl 1999). The first and second group more or less reflect the contrast between ILM and OLM systems. We define Belgium, France, the United Kingdom, and Ireland as ILM countries. Austria, Germany, Denmark, and the Netherlands are labelled OLM countries. As a third institutional context in Europe, which clearly differs from ILM and OLM countries (see Jobert 1997), we combine the Southern European countries Greece, Italy, Spain, and Portugal. Although there are some national differences within each country cluster, it seems that these country differences are minor to the clear contrasts between ILM, OLM, and Southern European countries (Gangl 1999). Therefore, this within-cluster crosscountry variation is ignored in the present analysis.

To control for differences in educational achievement, we introduce the level of education in the analysis. The level of education is measured in terms of ISCED (UNESCO 1975). We distinguish three levels of education: primary education plus lower secondary education (ISCED0-2), upper secondary education (ISCED3), and tertiary education (ISCED5-7). For the interpretation of the effects of education, we have to keep in mind that in the analysis the level of education reflects the highest achieved educational qualification so far, and that many young people who are still in initial education will potentially upgrade their level of education later on.

Gender differences with regard to the occurrence of double status positions are investigated by differentiating between men and women. Trends over time are determined by including a variable that measures the period of observation.

Three labour market outcomes of young people in a double status position are examined. First of all, we look at the permanency of the job as an indicator of job security. The permanency of the job is measured by distinguishing between permanent and temporary jobs. A temporary position reflects a job with a contract of limited duration. Secondly, the part-time versus fulltime contrast is analysed. This distinction is built on the subjective evaluation of the individual and not on the actual number of hours worked per week. Thirdly, we study the level of occupation attained. Besides a description of occupational groups, the occupational status of the jobs held by young people is analysed. The occupational groups are based on the first digit (major groups) of the ISCO-88 classification (ILO 1990). The occupational status of jobs is determined on the basis of the international socio-economic index (ISEI) (Ganzeboom, De Graaf and Treiman 1992; Ganzeboom and Treiman 1996). Status scores were assigned to occupational titles (based on 3-digit information from the ISCO-88 classification) according to a scale that ranges from 16 for occupations with the lowest status to 90 for occupations with the highest status. Armed forces are excluded from the analysis.

\section{Double status positions among young people}

Figure 2 presents the occurrence of double status positions among young people for various age groups in different institutional contexts. It is immediately evident upon inspection of this 
figure that there is a great deal of cross-country variation with regard to the education and employment activities of young people that can be linked systematically with the institutional context.

OLM countries are characterized by relatively high proportions of young people in a double status position. In most of these countries, the combination of learning and working is institutionalized by the apprenticeship system. The large proportion of dual system students confirms the strong link between education and employment in OLM countries. Especially in Germany and Austria, a relatively large proportion of young people is in the dual system. In Germany, this percentage amounts to almost one quarter of the total youth population of 1519 years old. In Denmark and the Netherlands, on the other hand, the percentage of young people in the dual system is lower, since vocational training is more often school-based in these countries. The relatively high proportion of double status positions in both countries (and also in Finland) can be attributed to the large number of young people who are in initial education and have part-time jobs at the same time. In Denmark, for instance, the proportion of working students amounts to 41 per cent in the age group of 15-19 years old persons.

In ILM countries, the occurrence of double status positions among young people is much lower. Only in the United Kingdom, and to some extent also in Ireland, a considerable group of young people is in a double status position as a studying worker or - only in the youngest age group - as a working student. Young people in both Anglo-Saxon countries enter the labour market at a rather early age, but a substantial part of them obtains job-specific skills via youth training schemes or evening and part-time programmes in institutions like Further Education in the United Kingdom. Furthermore, in France there is a small proportion of young people that is in the apprenticeship system.

In Southern Europe double statuses in youth transitions hardly occur. Working students and studying workers exist (mainly in Portugal), but only marginally. In the Southern European countries there seems to be a clear trade-off between school and work. Young people are either in the employment system or in education. Moreover, a substantial proportion of young people in Southern Europe is neither in education or training nor in employment (see Couppié and Mansuy 1999). Such youngsters run the risk of long-term economic and social exclusion and depend upon family support as a result of the lack of an adequate social security system (Bison and Esping-Andersen 2000).

When different age groups are compared, we find that the categories of dual system students and working students are clearly 'age-bounded'. The majority of dual system students and working students is aged between 15 and 24 years. The reason for this is obvious, since the purpose of the education or training received here is - by definition - initial. For studying workers, there is a less clear age restriction, although it seems that investments in continuous education or training mostly take place in the beginning of the occupational career. 
Figure 2

Occurrence of double status positions among young people by age group and country

15-19

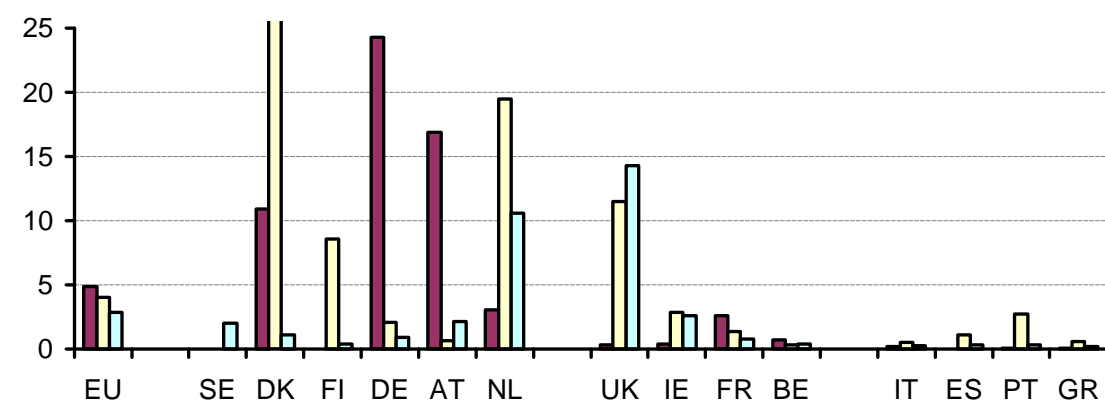

口dual system student

口working student

口studying worker

20-24

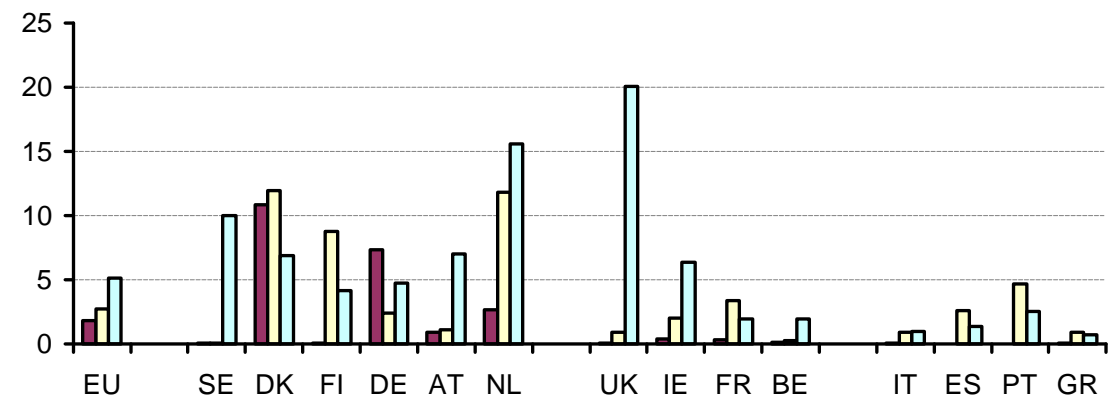

口dual system student 口working student 口studying worker

$25-29$

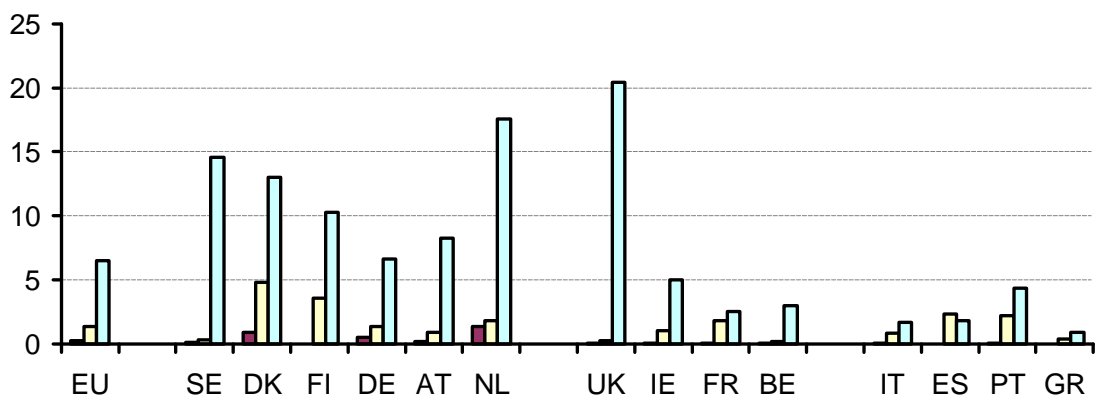

$\square$ dual system student $\square$ working student $\square$ studying worker

30-34

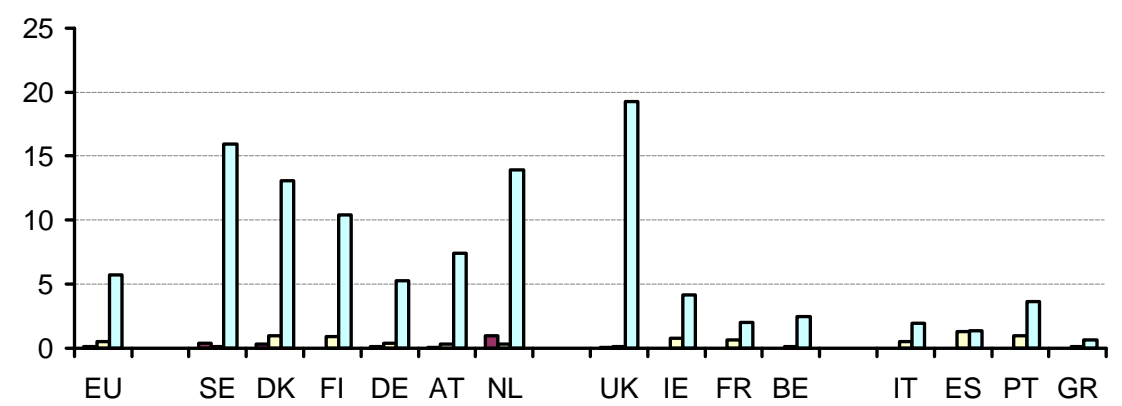

口dual system student $\square$ working student $\square$ studying worker 


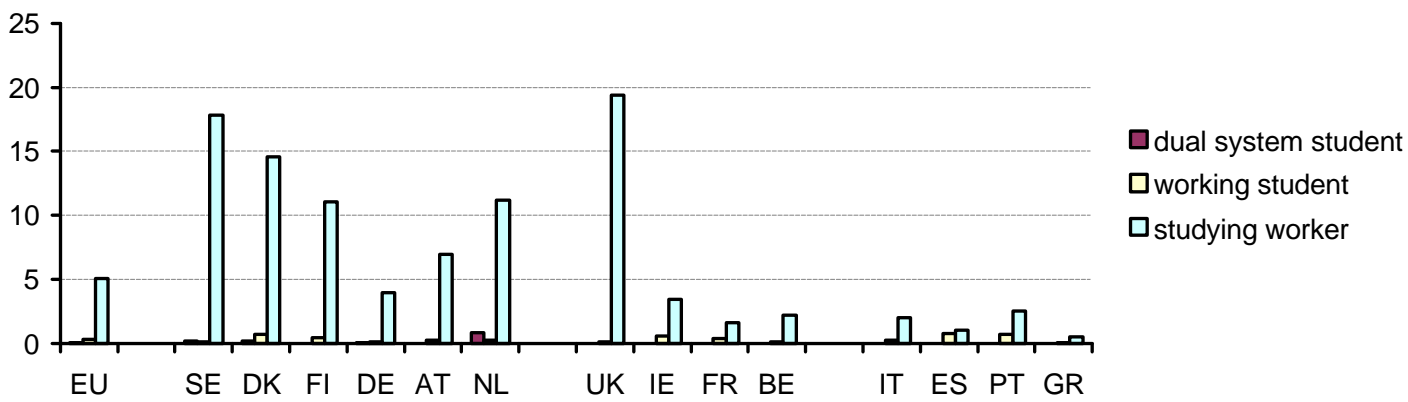

Source: pooled ECLFS-data 1992-97

In Table 1, the above-mentioned findings are refined by multinomial logit analysis. The table shows in a multivariate way the effects of various independent variables on the odds of being in a double status position relative to the odds of being in any other situation. Model 1 shows that the effects of the institutional context are reconfirmed by this analysis. It is clear that dual system students are found most often in OLM countries. The estimated odds ratio indicates that in OLM countries the odds of being a dual system student are more than 17 times larger than the corresponding odds in ILM countries. Also, the likelihood of being a working student is larger in OLM systems than in ILM ones. The implied odds ratio is 1.741. With respect to the likelihood of being a studying worker, the reverse is true. The results show that the odds of being a studying worker are higher in ILM countries than in OLM countries. In the former group of countries, the education system is hardly occupationspecific and therefore workers in these countries are often trained on-the-job. For Southern Europe, we find that young people in these countries have the lowest probability of being in any kind of double status position.

In addition, model 1 demonstrates that very young people are more often found in a double status position than less young people. As has been shown before, the negative age effects are strongest for dual system students and working students. Both double statuses are very much restricted to the youngest age groups.

With respect to the level of education attained so far, it is found that the lowest educated young people (ISCED0-2) have the highest probability of being a dual system student, followed by those with a certificate at the level of ISCED3. In contrast, the probability of being a working student or being a studying worker is highest among those with a degree in tertiary education (ISCED5-7).

Gender differences can be observed as well. The estimated odds ratio in model 1 shows that women are less likely to be in any double status position than men. Only with respect to the category of working students the gender effect is not significant. The odds of being a dual system student are 0.719 times smaller for women than for men; the odds of being a studying worker are 0.835 times smaller. 
Lastly, model 1 presents changes over time concerning the occurrence of double statuses in youth transitions. The conclusion that should be drawn from this model is that the probability of being a studying worker has increased over time. Despite the relatively short period of observation, the estimated time trend is positive and significant.

Table 1

Effects (in terms of odds ratios) of institutional context and other characteristics on being in a double status position

\begin{tabular}{|c|c|c|c|c|c|c|}
\hline \multirow[t]{2}{*}{ Model } & \multicolumn{3}{|c|}{1} & \multicolumn{3}{|c|}{2} \\
\hline & $\begin{array}{l}\text { Dual system } \\
\text { student }^{\mathrm{a}}\end{array}$ & $\begin{array}{l}\text { Working } \\
\text { student }^{\mathrm{a}}\end{array}$ & $\begin{array}{l}\text { Studying } \\
\text { worker }^{a}\end{array}$ & $\begin{array}{l}\text { Dual system } \\
\text { student }^{\mathrm{a}}\end{array}$ & $\begin{array}{l}\text { Working } \\
\text { student }^{\mathrm{a}}\end{array}$ & $\begin{array}{l}\text { Studying } \\
\text { worker }^{a}\end{array}$ \\
\hline \multicolumn{7}{|c|}{ Institutional context } \\
\hline ILM countries & ref. & ref & ref. & ref. & ref. & ref. \\
\hline OLM countries & $17.378^{\star \star}$ & $1.741^{\star *}$ & $0.808^{\star \star}$ & $21.436^{\star \star}$ & $1.828^{\star \star}$ & $1.106^{\star *}$ \\
\hline Southern Europe & $0.137^{\star *}$ & $0.574^{* *}$ & $0.185^{\star *}$ & $0.160^{\star *}$ & $0.634^{\star *}$ & $0.189^{* *}$ \\
\hline \multicolumn{7}{|l|}{ Age } \\
\hline $15-19$ & ref. & ref. & ref. & ref. & ref. & ref. \\
\hline $20-24$ & $0.452^{\star \star}$ & $0.483^{\star *}$ & $1.052^{*}$ & $0.455^{\star \star}$ & $0.483^{\star *}$ & $1.060^{* *}$ \\
\hline $25-29$ & $0.051^{* *}$ & $0.202^{\star *}$ & $1.123^{\star \star}$ & $0.051^{\star *}$ & $0.202^{\star \star}$ & $1.134^{* *}$ \\
\hline $30-34$ & $0.023^{\star \star}$ & $0.075^{\star \star}$ & $0.937^{\star *}$ & $0.023^{\star *}$ & $0.074^{\star *}$ & $0.948^{*}$ \\
\hline $35-39$ & $0.017^{* *}$ & $0.042^{* *}$ & $0.819^{* *}$ & $0.017^{\star *}$ & $0.042^{\star *}$ & $0.829^{* *}$ \\
\hline \multicolumn{7}{|l|}{ Level of education } \\
\hline ISCED0-2 & $4.502^{\star \star}$ & $0.370^{*}$ & $0.245^{\star \star}$ & $4.542^{\star \star}$ & $0.370^{* *}$ & $0.250^{* *}$ \\
\hline ISCED3 & $2.136^{* *}$ & $0.502^{* *}$ & $0.488^{* *}$ & $2.136^{\star \star}$ & $0.502^{* *}$ & $0.489^{* *}$ \\
\hline ISCED5-7 & ref. & ref. & ref. & ref. & ref. & ref. \\
\hline \multicolumn{7}{|l|}{ Female } \\
\hline Overall & $0.719^{* *}$ & 0.982 & $0.835^{\star \star}$ & & & \\
\hline ILM countries & & & & $0.439^{\star *}$ & $1.095^{\star \star}$ & $0.839^{* *}$ \\
\hline OLM countries & & & & $0.753^{\star *}$ & $0.932^{*}$ & $0.811^{* *}$ \\
\hline Southern Europe & & & & 0.812 & $0.917^{*}$ & $0.902^{* *}$ \\
\hline \multicolumn{7}{|c|}{ Time trend $(1992=0)$} \\
\hline Overall & 0.992 & 1.005 & $1.016^{\star \star}$ & & & \\
\hline ILM countries & & & & $1.146^{\star *}$ & 1.000 & $1.068^{* *}$ \\
\hline OLM countries & & & & $0.974^{\star *}$ & 1.013 & $0.948^{* *}$ \\
\hline Southern Europe & & & & 0.982 & 0.996 & $1.039^{* *}$ \\
\hline Model Chi ${ }^{2}$ & $71,261^{\star *}$ & & & $71,692^{\star *}$ & & \\
\hline Df & 30 & & & 42 & & \\
\hline Pseudo $\mathrm{R}^{2}$ & 0.190 & & & 0.191 & & \\
\hline $\mathrm{N}$ & 698,906 & & & 698,906 & & \\
\hline
\end{tabular}

${ }^{*}=\mathrm{p}<0.05 ;{ }^{* *}=\mathrm{p}<0.01 ;^{\mathrm{a}}=$ relative to any other position (i.e. employed; not in education, not employed; in education or not employed; not in education); ref. = reference category

Source:pooled ECLFS-data 1992-97 
To investigate whether changes over time vary across institutional contexts, statistical interaction terms of the institutional context with the time trend variable were estimated. In model 2 of Table 1 the main effects of the time trend variable are shown per institutional context. Interestingly, we find a negative time trend with regard to dual system students in OLM countries, indicating that the proportion of dual system students has declined in these countries recently. In ILM countries, on the other hand, the dual system has become more proliferated in the period 1992-97. With respect to the double status situation of being a studying worker, we find an increase in the likelihood of continuous training during the occupational career in ILM countries and in Southern Europe. In OLM countries, however, the probability of being a studying worker has decreased over time.

Interactions of the institutional context with gender were also empirically tested in model 2. The results show that the disadvantageous position of women with respect to participation in the dual system is much smaller in OLM countries than in ILM ones. With regard to working students, the odds ratios express that in ILM countries the effect of gender is positive - i.e. women are more likely to be a working student than men -, whereas in OLM countries and Southern Europe this effect is negative. Finally, with regard to studying workers we observe that the odds ratios for the different institutional contexts are quite close to each other, indicating that in all contexts women are underrepresented as a studying worker.

Summing up, the occurrence of double status positions among young people differs according to the various institutional contexts within Europe. Dual system participation is most relevant in OLM countries, in particular in Germany and Austria. Working students are most frequently found in OLM countries as well. Especially in Denmark and the Netherlands, student jobs are quite usual. Continuous training during working life is most common in ILM contexts, which is understandable from their little attention to occupation-specific skills in initial education. In Southern Europe, double status positions of any type hardly exist. With respect to changes over time, it is found that the proportion of studying workers has increased in Europe over the years. This finding especially holds for ILM countries. Participation in the dual system has increased as well in ILM countries, while it has decreased in OLM ones. Furthermore, it is observed that women are underrepresented in all double status positions. There is one exception: in ILM countries, women have a higher probability of being a working student than men.

\section{Labour market outcomes of young people in a double status position}

We now turn to three labour market outcomes of young people who are in a double status position: the odds of having a temporary job, the odds of having a part-time job and the occupational status attained. The aim is to gain more insight in the issue whether being in a double status situation facilitates or, rather, hinders the transition to a stable labour market position for young people. In the former case, double statuses are an effective step for young people towards stable employment. In the latter case, double status positions can be interpreted as some kind of trap that place young people in a persistent state of precarious work. Therefore, we investigate whether double statuses in youth transitions go together with 
specific employment situations that differ from the labour market position of those who are fully employed, and if so, whether there are institutional differences in this respect.

\section{Permanency of the job}

We begin with the permanency of the job. For this purpose, the results of logistic regression analysis of having a temporary job are presented in Table 2. This multivariate analysis shows that young people who are in a double status position are more likely to have a temporary job than those who are employed without being in education at the same time. For the contrast with dual system students, the estimated parameter shows that the odds for young people who are in an apprenticeship programme are more than 30 times larger than the corresponding odds for those who are only working. The implied odds ratios for working students and studying workers are 3.025 and 1.650 , respectively.

Table 2

Effects (in terms of odds ratios) of double status position and other characteristics on three labour market outcomes

Labour market outcome $\begin{gathered}\text { Having a } \\ \text { temporary job }\end{gathered} \begin{gathered}\text { Having a } \\ \text { part-time job }\end{gathered} \quad \begin{gathered}\text { Occupational } \\ \text { status }^{\mathrm{a}}\end{gathered}$

Double status position

Employed; not in education

Dual system student

Working student

Studying worker

Institutional context

ILM countries

OLM countries

Southern Europe

Age

15-19

20-24

25-29

30-34

35-39

Level of education

ISCED0-2

ISCED3

ISCED5-7

Female

Time trend $(1992=0)$

Model $\mathrm{Chi}^{2}$

Df

Pseudo $\mathrm{R}^{2}$

$\mathrm{N}$ ref.

$30.846^{* *}$

$3.025^{\star *}$
$1.650^{\star *}$

ref.

$0.924^{* *}$

$2.312^{* *}$

ref.

$0.883^{\star \star}$
$0.454^{* \star}$
$0.286^{\star \star}$
$0.215^{\star \star}$

$0.802^{\star *}$

$0.583^{\star *}$

ref.

$1.121^{\star}$
1.076
$44^{\star \star}$
13
0.223
47

ref.

$0.133^{* *}$

$18.211^{* *}$

$1.492^{* *}$

ref.

$1.174^{\star *}$

$0.319^{* *}$

ref.

$0.439^{\star *}$

$0.451^{* *}$

$0.633^{* *}$

$0.700^{* *}$

ref.

$3.071^{* *}$

$3.171^{* *}$

$4.174^{* *}$

ref.

$-1.884^{\star \star}$

0.073

ref.

$1.130^{* *}$

$3.114^{\star *}$

$4.113^{* *}$

n.a.

\footnotetext{
${ }^{*}=\mathrm{p}<0.05 ;{ }^{* *}=\mathrm{p}<0.01 ;{ }^{\mathrm{a}}=$ effects in terms of ISEI scores; ${ }^{\mathrm{b}}=\mathrm{F}$ instead of Model $\mathrm{Chi}^{2} ;{ }^{\mathrm{c}}=$ Adjusted $R^{2}$ instead of Pseudo $R^{2} ;$ n.a. = not available; ref. = reference category

Source: pooled ECLFS-data 1992-97
}

12 
Controlled for these differences between double status positions, there is an effect of the institutional context on the odds of having a temporary job. Young people in Southern Europe run the highest risk of being in a temporary position, followed by those from ILM countries. In OLM countries the probability of temporary employment among young people is lowest. In addition, the analysis shows that age has a negative effect on the odds of having a temporary job. This finding indicates that younger people are less well integrated into the labour market than older ones. Furthermore, females are more likely to be in a temporary labour market position than males. Moreover, young people with a certificate at the ISCED3level have the lowest probability of being in a temporary position, followed by the least qualified. Finally, the results demonstrate that temporary employment has increased over time. The odds of having a temporary job has risen by seven per cent each year.

In Table 3, the effects of being in a double status position are presented for each institutional context separately. The estimated odds ratios are based on the interaction terms of the institutional context variable with the double status categories. The results indicate that in ILM countries dual system students are far most often in a temporary labour market position, followed by those in OLM countries. In Southern Europe, the probability of having a temporary job for dual system students is lowest, although the odds for dual system students is still about five times higher than the odds for those who are regularly employed. With respect to working students, it can be concluded that the effects do not differ much between European contexts. For studying workers, ILM systems offer the best protection against temporary employment: there is no significant effect of being a studying worker on the odds of having a temporary job. In OLM countries, on the other hand, studying workers are most likely to have temporary contracts. The estimated odds ratio is 3.148 .

\section{Distinction between part-time and full-time employment}

In Table 2, the results of logistic regression analysis with regard to the odds of being in a part-time job are displayed as well. The coefficients show that working students are most likely to be in a part-time job. Compared to the odds of being in part-time relative to full-time employment for workers who are not in education, the corresponding odds for working students are approximately 18 times larger. The interpretation for this strong effect is obvious: full-time students have to combine their labour market activities in part-time jobs. For studying workers, a similar interpretation may explain their higher probability of being in part-time employment. Dual system students are less often in part-time jobs than employees who do not participate in any form of education or training.

In addition, the institutional context has a significant effect on the odds of having a part-time job. Compared to young people from ILM countries, those from OLM countries have a higher probability of being in part-time employment. Presumably, the relatively high rates of parttime employment in the Netherlands contribute to this effect (see Couppié and Mansuy 1999). In Southern European countries, part-time employment is still not conventional, as can be concluded from the negative effect for Southern Europe. 
The positive age effect indicates that the various age groups are at different stages of the transition process. Older people are more integrated into the labour market, as can be seen from their lower probability of being in a part-time job. In addition, the results show that women are more likely to have a part-time job than men, which is of course the result of women's larger (anticipated) responsibilities within the household. Furthermore, the lower educated run a higher risk of being employed in a part-time job than the higher educated. Lastly, a positive time trend is observed, indicating that the probability of part-time employment among young people has increased over time.

Table 3 again describes the effects of the double status positions by institutional context. The results show that the odds ratio of having a part-time job among dual system students is smaller than one in OLM countries. This indicates that in these countries dual system students are less often in part-time employment than regular workers. In Southern Europe, on the other hand, there is a positive effect of being a dual system student on the likelihood of part-time employment. The estimated odds ratio implies that the odds of having a parttime versus full-time job are more than four times higher for dual system students than for those who are employed, but not in education. With respect to working students, there are considerable differences between European contexts as well. In OLM countries, the odds ratio of being part-time employed for working students is much larger (40.277) than in ILM countries (16.200) and Southern Europe (7.498). Finally, being a studying worker in Southern Europe is more often in combination with having a part-time job than in other parts of Europe, although the differences between institutional contexts are rather modest compared to the two other double status categories.

\section{Occupational status attainment}

Before analysing the impact of being in a double status position on the occupational status attained by young people, we start this subsection with a brief look at the occupational structure of the jobs held. ${ }^{7}$ Despite the crude level of differentiation (ISCO-88 major groups), we find substantial differences in the occupational distribution, both with regard to double status position and institutional context (see Table 4). As expected, dual system students are most often employed as craft and related trades workers (37 per cent in total). This percentage is slightly higher in ILM countries and somewhat lower in OLM and Southern European countries. Furthermore, an important proportion of the dual system students is working in service and shop/market sales occupations, especially in ILM countries (23 per cent) and in Southern Europe (22 per cent). Moreover, in OLM countries and in Southern Europe, a substantial group of young people who combine learning and working in the dual system, holds jobs in clerk and technician level occupations. This latter finding suggests that in OLM and Southern European countries, the dual system serves more (higher skilled) occupations than in ILM countries. 
Table 3

Effects (in terms of odds ratios) of double status position on three labour market outcomes by institutional context

\begin{tabular}{|c|c|c|c|}
\hline & $\begin{array}{l}\text { Dual system } \\
\text { student }^{\mathrm{a}}\end{array}$ & $\begin{array}{l}\text { Working } \\
\text { student }^{\mathrm{a}}\end{array}$ & $\begin{array}{l}\text { Studying } \\
\text { worker }^{\mathrm{a}}\end{array}$ \\
\hline \multicolumn{4}{|c|}{ Having a temporary job } \\
\hline ILM countries & $97.905^{\star *}$ & $3.013^{\star \star}$ & 1.022 \\
\hline OLM countries & $34.216^{\star *}$ & $3.603^{* *}$ & $3.148^{\star *}$ \\
\hline Southern Europe & $4.818^{*}$ & $2.396^{*}$ & $1.303^{*}$ \\
\hline Model $\mathrm{Chi}^{2}$ & $51,239^{\star *}$ & & \\
\hline Df & 19 & & \\
\hline Pseudo $R^{2}$ & 0.228 & & \\
\hline $\mathrm{N}$ & 357,447 & & \\
\hline \multicolumn{4}{|c|}{ Having a part-time job } \\
\hline ILM countries & 1.083 & $16.200^{\star *}$ & $1.168^{\star *}$ \\
\hline OLM countries & $0.090^{\star \star}$ & $40.277^{\star *}$ & $1.883^{\star \star}$ \\
\hline Southern Europe & $4.108^{\star *}$ & $7.498^{\star *}$ & $2.440^{\star *}$ \\
\hline Model $\mathrm{Chi}^{2}$ & $73,013^{* *}$ & & \\
\hline Df & 19 & & \\
\hline Pseudo $R^{2}$ & 0.289 & & \\
\hline $\mathrm{N}$ & 412,702 & & \\
\hline \multicolumn{4}{|c|}{ Occupational status ${ }^{b}$} \\
\hline ILM countries & $1.937^{\star \star}$ & $4.011^{\star \star}$ & $4.899^{\star \star}$ \\
\hline OLM countries & $3.385^{\star \star}$ & $2.315^{\star \star}$ & $3.596^{\star \star}$ \\
\hline Southern Europe & $3.485^{\star \star}$ & $3.327^{\star \star}$ & $3.475^{\star *}$ \\
\hline $\mathrm{F}$ & $6,887^{* *}$ & & \\
\hline Df & 18 & & \\
\hline Adjusted $\mathrm{R}^{2}$ & 0.290 & & \\
\hline $\mathrm{N}$ & 303,413 & & \\
\hline
\end{tabular}

${ }^{*}=p<0.05 ;{ }^{* *}=p<0.01 ;{ }^{a}=$ relative to those who are employed, but not in education; ${ }^{b}=$ effects in $^{*}$ terms of ISEI scores; Note: the coefficients are from the interaction terms institutional context ${ }^{*}$ double status position; main effects are included in the model; controlling for age, level of education, female and time trend.

Source: pooled ECLFS-data 1992-97

Almost half of the working students' jobs are service and shop/market sales occupations and elementary occupations. In ILM countries, the former occupations are more frequent. In OLM ones, the latter occupations are more common, which is in line with the argument that in these labour markets access to other than elementary jobs is not possible without the required skills. In all institutional contexts, the most usual occupations (not presented in Table 4) are shop sales jobs (14 per cent in total), housekeeping and restaurant service jobs (8 per cent), and domestic and cleaning jobs (5 per cent). In addition, a relatively large proportion of working students has access to higher-skilled occupations (clerical and professional jobs), possibly related to their type of study in (tertiary) education. 
Continuous training during the occupational career is concentrated in higher skilled occupations. Studying workers can in particular be found among professionals ( 21 per cent), technicians (21 per cent) and clerks (18 per cent). There are some minor differences between institutional contexts. Studying workers originating from ILM countries are somewhat over-represented in professional occupations, those from OLM countries in technician level occupations and those from Southern Europe in clerical jobs.

Returning to Table 2, we find the results of linear regression analysis of the occupational status of the jobs held by young people in a double status position. The regression coefficients indicate that the ISEI occupational status score for young people in any kind of double status position is higher than for those who are employed, but not in education. For studying workers, the average occupational status of the jobs held is about four points higher, followed by working students and dual system students who both hold jobs for which the occupational status score is on average three points higher than for regular employees.

In addition, the findings display that the occupational status attained by young people in OLM countries is almost two points lower than in ILM countries. The age dummies show that age has a positive effect on status attainment, most likely referring to the fact that individuals with working experience achieve higher job levels than those without. The gender effect indicates that women are in an advantageous position in terms of occupational status. Moreover, the level of education obtained has a strong positive effect on the attainment of occupational status. The jobs held by the least qualified have much less status than the jobs performed by the highest educated. The estimated difference is 21 points on the occupational status scale. Finally, the results in Table 2 show that the occupational returns have declined over time. However, the implied loss in status attainment among young people is fairly small: only one point in the observed period of five years $\left(5^{*}-0.196=-0.980\right)$.

In Table 3, the occupational status attained by young people in a double status position is broken down by the institutional context. The results show that the occupational status achieved by dual system students in OLM countries and Southern Europe is around one-anda-half points higher than in ILM countries. This finding presumably refers to the observation that in the former set of countries dual system students more often work as technicians and associate professionals or clerks; occupational groups that are rather prestigious in the labour market. With respect to the categories of working students and studying workers we find the opposite. In ILM countries, the jobs that young people in these double status positions hold have relatively more occupational status than in OLM countries and Southern Europe.

In summary, then, double status positions go together with specific employment situations that sometimes differ between institutional contexts. Dual system participants combine fixedterm contracts with full-time employment, while studying workers are not very different from their non-studying colleagues. Working students are more often employed on a part-time basis. Nevertheless, the permanency of these student jobs is fairly high, at least much closer to the situation of regular employees rather than to that of dual system students. Also with regard to the occupational level of the jobs held by young people there are substantial differences between double status positions. 
Table 4

Occupational structure of jobs held by young people in a double status position by institutional context

\begin{tabular}{|c|c|c|c|c|}
\hline & $\begin{array}{c}\text { Dual } \\
\text { system } \\
\text { student } \\
\%\end{array}$ & $\begin{array}{c}\text { Working } \\
\text { student } \\
\%\end{array}$ & $\begin{array}{c}\text { Studying } \\
\text { worker } \\
\%\end{array}$ & $\begin{array}{c}\text { Employed; } \\
\text { not in } \\
\text { education } \\
\%\end{array}$ \\
\hline \multicolumn{5}{|l|}{ Overall } \\
\hline Legislators, senior officials and managers & 1 & 2 & 8 & 5 \\
\hline Professionals & 2 & 14 & 21 & 9 \\
\hline Technicians and associate professionals & 14 & 12 & 21 & 14 \\
\hline Clerks & 13 & 16 & 18 & 15 \\
\hline Service workers and shop/market sales workers & 18 & 27 & 12 & 15 \\
\hline Skilled agricultural and fishery workers & 2 & 2 & 1 & 3 \\
\hline Craft and related trades workers & 37 & 7 & 11 & 19 \\
\hline Plant and machine operators and assemblers & 3 & 3 & 4 & 10 \\
\hline Elementary occupations & 11 & 17 & 4 & 10 \\
\hline \multicolumn{5}{|l|}{ ILM countries } \\
\hline Legislators, senior officials and managers & 2 & 3 & 13 & 7 \\
\hline Professionals & 6 & 16 & 25 & 11 \\
\hline Technicians and associate professionals & 6 & 10 & 15 & 13 \\
\hline Clerks & 9 & 16 & 19 & 18 \\
\hline Service workers and shop/market sales workers & 23 & 34 & 13 & 15 \\
\hline Skilled agricultural and fishery workers & 3 & 1 & 1 & 3 \\
\hline Craft and related trades workers & 44 & 6 & 8 & 15 \\
\hline Plant and machine operators and assemblers & 5 & 3 & 4 & 11 \\
\hline Elementary occupations & 4 & 11 & 3 & 8 \\
\hline \multicolumn{5}{|l|}{ OLM countries } \\
\hline Legislators, senior officials and managers & 0 & 2 & 5 & 4 \\
\hline Professionals & 1 & 12 & 16 & 9 \\
\hline Technicians and associate professionals & 17 & 14 & 28 & 19 \\
\hline Clerks & 14 & 14 & 16 & 14 \\
\hline Service workers and shop/market sales workers & 16 & 23 & 11 & 14 \\
\hline Skilled agricultural and fishery workers & 2 & 2 & 1 & 2 \\
\hline Craft and related trades workers & 35 & 6 & 14 & 21 \\
\hline Plant and machine operators and assemblers & 2 & 3 & 4 & 9 \\
\hline Elementary occupations & 14 & 25 & 6 & 9 \\
\hline \multicolumn{5}{|l|}{ Southern Europe } \\
\hline Legislators, senior officials and managers & 0 & 2 & 2 & 3 \\
\hline Professionals & 3 & 15 & 20 & 7 \\
\hline Technicians and associate professionals & 15 & 14 & 23 & 11 \\
\hline Clerks & 16 & 23 & 21 & 14 \\
\hline Service workers and shop/market sales workers & 22 & 21 & 14 & 17 \\
\hline Skilled agricultural and fishery workers & 1 & 2 & 1 & 4 \\
\hline Craft and related trades workers & 31 & 10 & 10 & 22 \\
\hline Plant and machine operators and assemblers & 7 & 4 & 5 & 10 \\
\hline Elementary occupations & 5 & 10 & 5 & 12 \\
\hline
\end{tabular}

Source: pooled ECLFS-data 1992-97 


\section{Conclusion}

The labour market entry of young people is a transition process of which it is not easy to determine when it really starts and ends. In many cases, there is a kind of gradual entry into the labour market, during which young people are simultaneously both student and worker. In this paper we investigated the extent, structure, and recent development of combinations between learning and working within the European Union. These double status positions refer to pupils participating in a dual system of apprenticeship training, full-time students having jobs and young workers investing in on-the-job-training to advance their occupational career. Furthermore, this paper is concerned with the labour market position of young people in double statuses. To what extent do double status positions among young people go together with specific employment situations that differ from the labour market position of those who are regularly employed?

We started from the assumption that the occurrence of double status positions during the transition process differs between European countries according to their labour market structure and - inherent to that - the organization and set-up of their education and training system. In internal labour markets (ILM), newcomers on the labour market start in entrance jobs and by means of on-the-job-training they acquire the relevant occupational skills. In occupational labour markets (OLM), on the contrary, vocational training already takes place within the education and training system (irrespective whether this training is school-based or via an apprenticeship system) and access to skilled jobs is only possible with adequate qualifications. Consequently, the importance of double status positions is shaped by the location where the skills production takes place and the accessibility of skilled jobs. This implies that studying workers are more likely to be found in ILM countries than in OLM ones, whereas the opposite is expected with regard to dual system students. It further implies that in countries dominated by an ILM structure relatively more students work than in OLM contexts, since in ILM arrangements unskilled or low-skilled jobs are more easily accessible without the proper qualifications, because of the entry port employment structure there.

In general, our empirical analysis is consistent with these hypotheses. Despite a strong and equal link with age in all countries, the occurrence of double status positions among young people differs according to the institutional context. Continuous training during early working life is most common in countries with an ILM structure, which is understandable from their little vocational orientation in initial education. Dual system participation, on the other hand, is most relevant in OLM countries, in particular in Germany and Austria. Only with respect to the category of working students our hypothesis is falsified. Working students are most frequently found in OLM countries. Especially in Denmark and the Netherlands, a relatively large proportion of the students work. In Southern Europe, double status positions of any type hardly exist. After initial education, young people in these countries are either employed in a stable job or outside the labour force, running the risk of long-term economic and social exclusion and depending upon family support.

With respect to recent changes over time, it is observed that the likelihood of continuous training during the early occupational career has increased in ILM countries and in Southern 
Europe. In OLM countries, on the other hand, the probability of being a studying worker has decreased over time. Interestingly enough, we found a negative time trend with regard to dual system participation in OLM countries as well, indicating that the proportion of dual system students has declined in these countries recently. In ILM countries, on the other hand, the dual system has become more proliferated lately. This finding supports the notion that countries such as France have been successful recently in their attempts to enlarge the involvement of firms and employers in the provision of apprenticeships (Goux and Maurin 1998; Crouch, Finegold and Sako 1999).

Furthermore, it is shown that women are underrepresented in all double status positions. There is one exception: in ILM countries, women have a higher probability of being a working student than men. Another conclusion with respect to gender differences is that the disadvantageous position of women regarding dual system participation is smaller in OLM countries than in ILM ones.

Comparing the job characteristics of young people in a double status position with these of regular workers, we found interesting differences that vary across countries. In general, double statuses in youth transitions go together with specific employment situations. Participants in a dual system often combine fixed-term contracts with full-time employment. In Southern Europe, dual system students have much less often a temporary job than in ILM countries and OLM countries. In the former case, however, part-time employment among dual system students is more frequent. Working students, in turn, are more frequently employed on a part-time basis, especially in countries with an OLM structure. Nevertheless, the permanency of student jobs is found to be fairly high, at least much closer to the situation of regular employees rather than to that of dual system students. Studying workers are not found to be much different from their non-studying colleagues. However, one finding deserves special attention. It is shown that studying workers in ILM countries are less often employed on a temporary basis than in OLM ones. This result indicates that additional training in the early working life is explicitly embedded in the labour market structure of the former set of countries.

With respect to the occupations held by young people in a double status position, it is observed that dual system students are often employed as craft and related trades workers or as service and shop/market sales workers. More important, in OLM countries and Southern Europe, the dual system serves a broader range of (higher skilled) occupations than in ILM ones. Working students usually hold service and shop/market sales occupations or elementary occupations. In OLM countries, the former occupations are less frequent and the latter ones more than in ILM countries, which is consistent with the assumption that in the former institutional context access to other than elementary jobs is not easy without the proper qualifications. Studying workers are mainly found among professionals, technicians, and clerks. There are hardly any institutional differences in this respect. In terms of status attainment, studying workers achieve the highest occupational status with their jobs, closely followed by working students and dual system students. The relative status position of dual system students is higher in OLM countries and Southern Europe than in ILM countries, 
whereas the opposite holds for the status attainment of working students and studying workers.

In view of these findings, can it be concluded that combining education and work leads to better opportunities for young people to find stable employment? In general, it is assumed that early work experience provides individuals with job-related skills that are recognized as such by employers. Especially the provision of apprenticeship programmes may contribute to this. Although we observed in this paper that dual system students often have fixed-term labour contracts, it has been shown in much other research that the employment opportunities for dual system leavers are relatively good. This implies that dual system students, when they have to leave the firm after finishing the apprenticeship system, rather easily find a new job with another employer. With respect to continuous training a similar conclusion can be drawn. The data used in this paper have demonstrated that studying workers are more often employed on a temporary and/or part-time basis than regular employees, but at the same it is a known fact that investments in on-the-job-training have a positive rate of return on the labour market (see for example Groot and Mekkelholt 1995). Even with regard to student jobs - often containing unskilled or low-skilled work -, there is some empirical evidence that working while in education has a positive effect on later labour market outcomes (Carr, Wright and Brody 1996). So, double status positions themselves are not very promising - in the sense that we are dealing here with secure, high status jobs -, but it looks like that combinations between education and work must be interpreted first of all as investments in specific human capital that are paid off later on. In that sense, double status positions seem to act as a bridge between full-time initial education and stable employment for young people. A more definitive answer to this question, however, can only be formulated when more detailed insight is obtained in the full transition process. For that purpose, the cross-sectional approach applied in this paper is inappropriate and instead of that longitudinal data based on panel or cohort studies are needed.

\section{Notes}

* This paper has been prepared as part of the CATEWE research project (A Comparative Analysis of Transitions from Education to Work in Europe) funded under the TSER programme of the European Commission (Contract SOEZ-CT97-2019-CATEWE). Comments and suggestions from CATEWE members, notably Thomas Couppié, Markus Gangl, Damian Hannan, Michèle Mansuy, Walter Müller, and David Raffe are gratefully acknowledged.

1. More recently, the function of additional training is often being associated with the idea of lifelong learning. In current knowledge societies, where technological developments follow each other rapidly, the risk of skills becoming obsolete is relatively high and training is used to maintain and develop (new) skills (see for instance Bartel, 1991; Tuijnman, 1997).

2. Data from Luxembourg are excluded from the analysis due to small sample sizes. Data from Sweden and Finland are solely used when presenting the occurrence of double status positions in Europe. Since complete information on labour market outcomes is available for 1997 only, data from both countries are excluded from any further analysis in this paper. 
3. We define the employed labour force as those individuals who worked at least one hour in the week they were interviewed or those who did not work but had a job from which they were absent during the reference week.

4. This distinction implies that the education and training activities of unemployed persons are not treated separately. Instead, these individuals are classified within the group of individuals who are not employed, but in education.

5. Since the period of data collection of the ECLFS is in the Spring, i.e. immediately before the exams, students who work (either as dual system student or as working student) may be underrepresented in the data set. Furthermore, only in Spain, France, the Netherlands, Portugal, and the United Kingdom, persons in student homes are included in the survey. Also, with respect to the (purpose of the) education and training received during the last four weeks, there are some limits with regard to the degree of comparability of the information. This implies that the differences found between the countries need to be interpreted very carefully.

6. Due to the small number of respondents in double status positions within countries, we categorise in the remainder of this paper the yearly ages in five-year span age groups.

7. Since information on the purpose of the received education or training is lacking for this analysis, the double status categories are defined somewhat differently. We use the age variable as a proxy to determine the purpose of training. If respondents belong to the two youngest age groups (15-19 and 20-24 years of age), their purpose of training is defined as initial, whereas for older individuals the purpose of training is specified as continuous training. In addition, information on the oldest age group is not available for this analysis due to restricted data access.

\section{References}

Arrow, K. (1973), 'Higher education as a filter'. Journal of Public Economics, 2: 193-216.

Barron, J., D. Black \& M. Loewenstein (1989), 'Job matching and on-the-job training'. Journal of Labor Economics, 7: 1-19.

Bartel, A. (1991), Productivity gains from implementation of employee training programs. (NBER Working Paper Series 3893). Cambridge, MA: National Bureau of Economic Research.

Bison, I. \& G. Esping-Andersen (2000), 'Unemployment, welfare regime and income packaging'. In D. Gallie and S. Paugam (eds.), Welfare regimes and the experience of unemployment in Europe (pp. 69-86). Oxford: Oxford University Press.

Blossfeld, H-P. (1992), 'Is the German dual system a model for a modern vocational training system? A cross-national comparison of how different systems of vocational training deal with the changing occupational structure'. International Journal of Comparative Sociology, 23: 168-81.

Carr, R., J. Wright \& C. Brody (1996), 'Effects of high school work experience a decade later. Evidence from the National Longitudinal Survey'. Sociology of Education, 69: 66-81.

Crouch, C., D. Finegold \& M. Sako (1999), Are skills the answer? The political economy of skill creation in advanced industrial countries. Oxford: Oxford University Press.

Couppié, Th. \& M. Mansuy (1999), New entrants on European labour markets. In: W. Müller et al. (eds.), A comparative analysis of transitions from education to work in Europe - Based on the European Community Labour Force Survey (pp. 57-98). Mannheim, Maastricht, Marseilles: MZES, ROA, CEREQ.

Delsen, L. (1995), Atypical employment. An international perspective. Causes, consequences and policy. Groningen: Wolters-Noordhoff.

Doeringer, P. \& M. Piore (1971), Internal labor markets and manpower analysis. Lexington: Heath.

Eyraud, F., D. Marsden \& J-J Silvestre (1990), 'Occupational and internal labour markets in Britain and France'. International Labour Review, 129: 501-17. 
Gangl, M. (1999), European perspectives on labour market entry: a matter of occupationalised versus flexible arrangements in labour markets? In: W. Müller et al. (eds.), A comparative analysis of transitions from education to work in Europe - Based on the European Community Labour Force Survey (pp. 129-164). Mannheim, Maastricht, Marseilles: MZES, ROA, CEREQ.

Ganzeboom, H., P. de Graaf \& D. Treiman (1992), 'A standard international socio-economic index of occupational status'. Social Science Research, 21: 1-56.

Ganzeboom, H. \& D. Treiman (1996), 'Internationally comparable measures of occupational status for the 1988 International Standard Classification of Occupations'. Social Science Research, 25: 201-39.

Goux, D. \& E. Maurin (1998), 'From education to first job. The French case'. In Y. Shavit and W. Müller (eds.), From school to work. A comparative study of educational qualifications and occupational destinations (pp. 103-41). Oxford: Clarendon Press.

Groot, W. \& E. Mekkelholt (1995), The rate of return to investments in on-the-job-training. Applied Economics, 27, 173-182.

Hakim, C. (1998), Social change and innovation in the labour market. Oxford: Oxford University Press.

Hannan, D., D. Raffe \& E. Smyth (1997), 'Cross-national research on school to work transitions. An analytical framework'. In P. Werquin, R. Breen and J. Planas (eds.), Youth transitions in Europe: theory and evidence (pp. 409-42). Proceedings of third ESF workshop of the Network on Transitions in Youth, La Ciotat, September 1996. Marseilles: CEREQ.

Hutson, S. \& W-Y Cheung (1992), 'Saturday jobs: sixth-formers in the labour market and in the family'. In C. Marsh and S. Arber (eds.), Families and households: divisions and change (pp. 4562). Basingstoke: Macmillan.

ILO (1990), ISCO-88 International Standard Classification of Occupations. Geneva: ILO.

Jobert, A. (1997), 'Employment, education and training in Italy. The role of regions, employers' organisations and unions'. In A. Jobert, C. Marry, L. Tanguy and H. Rainbird (eds.), Education and work in Great Britain, Germany and Italy (pp. 208-23). London: Routledge.

Kerckhoff, A. (2000), 'Transition from school to work in comparative perspective'. In M. Hallinan (ed.), Handbook of the sociology of education (pp.543-74). New York/Boston: Kluwer Academic/Plenum Publishers.

Marsden, D. (1990), 'Institutions and labour mobility. Occupational and internal labour markets in Britain, France, Italy, and West Germany'. In R. Brunetta and C. Dell'Aringa (eds.), Labour relations and economic performance (pp. 414-38). Houndmills: Macmillan.

Maurice, M., F. Sellier \& J-J Silvestre (1986), The social foundations of industrial power: a comparison of France and Germany. Cambridge: MIT Press.

Mayer, K.U. (1995), 'Das duale system der beruflichen Ausbildung. Ultrastabilität oder Auflösung?'. In Hoff, E. \& L. Lappe (eds.), Verantwortung im Arbeitsleben (pp.89-98). Heidelberg: Roland Asanger Verlag.

Meer, P. van der \& R. Wielers (2001), 'The increased labour market participation of Dutch students'. Work, Employment, and Society, 15: 55-71.

Müller, W. \& Y. Shavit (1998), 'The Institutional Embeddedness of the Stratification Process, a Comparative Study of Qualifications and Occupations in Thirteen Countries'. In Y. Shavit and W. Müller (eds.), From school to work. A comparative study of educational qualifications and occupational destinations (pp. 1-48). Oxford: Clarendon Press.

Müller, W. \& M. Wolbers (1999), Educational attainment of young people in the European Union: cross-country variation of trends over time. In: W. Müller et al. (eds.), A comparative analysis of transitions from education to work in Europe - Based on the European Community Labour Force Survey (pp. 19-56). Mannheim, Maastricht, Marseilles: MZES, ROA, CEREQ.

OECD (1994), Vocational training in the Netherlands: Reform and innovation. Paris: OECD.

OECD (1996), Education at a glance. Analysis. Paris: OECD. 
OECD (1998), Employment Outlook. Paris: OECD.

OECD (1999), Employment Outlook. Paris: OECD.

OECD (2000), From initial education to working life. Making transitions work. Paris: OECD.

Scherer, S. (2001), 'Early career patterns. A comparison of Great Britain and West Germany'. European Sociological Review, 17: 119-44.

Shavit, Y. \& W. Müller (2000), 'Vocational secondary education. Where diversion and where safety net?'. European Societies, 2: 29-50.

Smoorenburg, M. van \& R. van der Velden (2000), 'The training of school-leavers. Complementarity or substitution?'. Economics of Education Review, 19: 207-17.

Thurow, L. (1975), Generating inequality. New York: Basic Books.

Tuijnman, A. (1997), 'Economics of adult education and training'. Adult Education and Development, 49: $189-198$.

UNESCO (1975), International Standard Classification of Education (ISCED). Paris: UNESCO. 
